\title{
Awareness and Practices of Personal Hygiene among Selected Rural School Children
}

\author{
Rahman $\mathrm{MM}^{1}$, Rahman $\mathrm{MM}^{2}$, Zafreen $\mathrm{F}^{3}$, Ahsan $\mathrm{MS}^{4}$, Uddin $\mathrm{ANMM}^{5}$ \\ DOI: https://doi.org/10.3329/jafmc.v13i2.41375
}

\begin{abstract}
Introduction: Poor hygiene practices and inadequate sanitary conditions play major roles in the increased burden of communicable diseases within developing countries.
\end{abstract}

Objective: To assess the status of awareness and practice about personal hygiene among the rural school children.

Materials and Methods: This cross sectional descriptive study was conducted from March 2015 to June 2015 among children of class IX and $X$ of a high school of Hemayetpur union of Savar area under Dhaka district. A total of 109 children were selected through purposive sampling and data were collected through face to face interview with a pretested semi-structured questionnaire.

Results: Students' mean age was $14.65 \pm 1.93$ years and $53.21 \%$ was boy. Majority $(57.80 \%)$ of the respondents' parents' monthly income was below 5000 taka and $42.20 \%$ were living in kacha house. Maximum $98.2 \%$ respondents had good knowledge that washing hand before meal and after defecation prevent transmission of disease and $62.21 \%$ had good hygiene practice habit. The association of type of residence with hand washing habit and wearing shoes in toilet was significant $(P<0.05)$. Significant $(p<0.01)$ association was also found among monthly family income and parents education status with daily bathing practice.

Conclusion: Almost all the students had agreed that washing hand before meal and after defaecation prevents the spread of diseases. Proper knowledge and practice on personal hygiene keep them away from many diseases. So, effort should be made to aware every school going children about the benefits of regular practice of personal hygiene for a bright and healthy life.

Key-words: Awareness, Personal hygiene, Rural school children.

\section{Introduction}

The word "hygiene" is derived from Hygeia, the goddess of health of Greek mythology. Hygiene is defined as "the science of health and embraces all factors which contribute to healthful living" ${ }^{1}$. Personal hygiene means health care which are the measures responsible for improving the health of the individual. Personal hygiene comprises a broad range of day to day activities, such as care of the body regarding bathing and washing, care of the clothing, care of teeth, nails, hair, posture etc. Personal hygiene includes all those personal factors which influence the health and well being of an individual ${ }^{2}$.

Poor knowledge and practice of and attitudes to personal hygiene such as hand washing play major roles in the high incidence of communicable diseases and therefore has negative consequences for a child's long term overall development ${ }^{1}$. Studies have revealed a strong and consistent causal link between poor hand hygiene and gastrointestinal infection ${ }^{2}$. Good hand hygienic practices encouraged through health education has been reported to be associated with low prevalence of communicable diseases in school children ${ }^{3}$. Personal hygienic practices therefore plays an important role in preventing spread of respiratory infections, helminthiasis, skin infections, eye infections, food borne diseases, spread of new pathogens as in epidemics ${ }^{3}$. Infectious disease causes $62 \%$ and $31 \%$ of all deaths in Africa and Southeast Asia respectively ${ }^{4}$.

The health of school children is a common concern of the school, parents and the community. A child has to be healthy to learn and the school is an important place, next to home, where a child learns to be healthy ${ }^{5}$. The relationship between health, education and development is very important, as a healthy child is the major input for human resources development ${ }^{6}$. Health and education are interrelated means of development. The schools are particularly important because these institutions represent gathering places for a population of age 5-17 years ${ }^{7}$. They are susceptible to many communicable diseases and vulnerable to physical and mental hazards. Moreover, a considerable proportion of school children, particularly in the underdeveloped and developing countries, suffer from malnutrition and deficiency diseases and as such they naturally desire special attention for their physical and intellectual development ${ }^{5,8}$.

1. Lt Col Md Masudur Rahman, MBBS, MPH, Trainee Officer, AFMI, Dhaka 2. Maj Gen Md Mahbubur Rahman, MBBS, MMEd, MCPS, DPH, Commandant, AFMC, Dhaka. 3. Dr Farzana Zafreen, MBBS, MPH, Associate Professor \& Head, Department of Community Medicine, Medical College for Women \& Hospital, Uttara, Dhaka 4. Lt Col Md Shamim Ahsan, MBBS, MPH, Commading Officer, 15 Field Ambulance, Ghatail 5. Lt Col Abu Noman Mohammed Mosleh Uddin, MBBS, MPH, MPhil, Associate Professor of Community Medicine, AFMC, Dhaka. 
It is generally recognized that childhood is the best time to learn hygiene behaviors. Children are future parents and what they learn is likely to be applied in the rest of their lives. They have important roles in the household, taking care of younger brothers and sisters, and depending on the culture, they may also question existing practices in the household. They are eager to learn and help, and if they consider environmental care and their role in this as important, they will take care of their own health and the health of others. Hand washing with soap behaviour under water and sanitation program" by UNICEF found that washing hands with soap at the right times can reduce instances of diarrhoea by $45-50$ percent ${ }^{9}$. Knowledge and practices on basic personal hygiene among school children have shown that although a sizeable number of the children studied had adequate knowledge related to basic personal hygiene, their practices related to same was poor ${ }^{3}$.

Maximum research works have been conducted on personal hygiene of various professionals. Very few have been done to assess awareness of school children. This study was conducted to get the information about awareness and practice status of rural students about their personal hygiene. This might give the guidelines for policymaker for planning and preparation of curriculum to conduct intervention program for students.

\section{Materials and Methods}

This descriptive cross sectional study was conducted among 109 children of class IX and X of a high school of Hemayetpur Union of Savar area under Dhaka District during March to June in 2015. Respondents were selected through purposive sampling irrespective of age, sex and religion who were responsive and agreed to participate were included in the study and data were collected through face to face interview with a pretested semi-structured questionnaire. Permission was obtained from the school authority and verbal consent from the participant. Data obtained were collated and analyzed by using the SPSS version 20.0. The data was presented in the form of frequency and percentage. Chi-square test was done to see association where and whenever required and $p<0.05$ considered as significant.

\section{Results}

Children's mean age was $14.65 \pm 1.93$ years and more than half $(53.2 \%)$ of the respondents belonged to the age of 14 years. More than half $(53.2 \%)$ were boys and majority were Muslim (89.9\%), 42.2\% were resident of kacha house. Around $68.8 \%$ of the respondents had the family size of $5-8$ members with a mean family size $4.9 \pm 1.89$ (Table-I).
Table-l: Distribution of socio-demographic characteristics of the respondents $(n=109)$

\begin{tabular}{|l|l|c|c|}
\hline \multicolumn{2}{|l|}{ Characteristics of the respondents } & Frequency & \% \\
\hline \multirow{4}{*}{ Age } & 14 years & 58 & 53.2 \\
\cline { 2 - 4 } & 15 years & 31 & 28.4 \\
\cline { 2 - 4 } & 16 years & 20 & 18.3 \\
\hline \multirow{3}{*}{ Rex } & Boys & 58 & 53.2 \\
\cline { 2 - 4 } & Girls & 51 & 46.8 \\
\hline \multirow{3}{*}{ Residence type } & Islam & 98 & 89.9 \\
\cline { 2 - 4 } & Hindu & 11 & 10.1 \\
\cline { 2 - 4 } & Pucca & 33 & 30.3 \\
\cline { 2 - 4 } & Semi Pucca & 30 & 27.5 \\
\hline \multirow{3}{*}{ Family size } & $\leq 4$ & 46 & 42.2 \\
\cline { 2 - 4 } & $5-8$ & 26 & 26.6 \\
\cline { 2 - 4 } & $\geq 9$ & 5 & 68.8 \\
\hline
\end{tabular}

Majority $(80.7 \%)$ of the respondents have the habit of washing hand before taking meal, whereas $94.5 \%$ have the habit of washing hand after defecation and $77.1 \%$ respondents wear shoes during use of toilet and $64.2 \%$ had the habit of taking daily bath (Table-II).

Table-Il: Distribution of respondents by their hygiene practices $(n=109)$

\begin{tabular}{|l|l|r|r|}
\hline Category & Response & \multicolumn{1}{|c|}{$\mathbf{n}$} & \multicolumn{1}{c|}{$\%$} \\
\hline \multirow{2}{*}{$\begin{array}{l}\text { Hand washing habit } \\
\text { before taking meal }\end{array}$} & Yes & 88 & 80.7 \\
\cline { 2 - 4 } Washing habit after & No & 21 & 19.3 \\
\hline \multirow{2}{*}{$\begin{array}{l}\text { Wearing shoes during use } \\
\text { of toilet }\end{array}$} & Yes & 103 & 94.5 \\
\cline { 2 - 4 } & No & 06 & 5.5 \\
\hline \multirow{3}{*}{ Habit of taking daily bath } & Yes & 84 & 77.1 \\
\hline \multirow{3}{*}{$\begin{array}{l}\text { Source of information } \\
\text { regarding personal }\end{array}$} & Yes & 25 & 22.9 \\
\cline { 2 - 4 } & No & 70 & 64.2 \\
\cline { 2 - 4 } & Teacher & 39 & 35.8 \\
\cline { 2 - 4 } & Family & 15 & 13.8 \\
\cline { 2 - 4 } & Health worker & 61 & 56.0 \\
\cline { 2 - 4 } & Others & 22 & 20.2 \\
\hline \multirow{3}{*}{ Habit of regular nail cutting } & After 7 days & 11 & 9.0 \\
\cline { 2 - 4 } & After 15 days & 6 & 92.7 \\
\cline { 2 - 4 } & After 1 month & 2.5 \\
\hline \multirow{3}{*}{ Timing of Cleaning teeth } & Early morning & 98 & 89.9 \\
\cline { 2 - 4 } & After every meal & 6 & 5.5 \\
\cline { 2 - 4 } & Before sleep & 5 & 4.6 \\
\hline \multirow{3}{*}{ Habit of cleaning cloth } & Everyday & 38 & 34.9 \\
\cline { 2 - 4 } & Twice in a week & 47 & 43.1 \\
\cline { 2 - 4 } & Once in a week & 24 & 22.0 \\
\hline
\end{tabular}

Students having kacha residence had significantly $(p<0.01)$ less hand washing practice than other types of residence (Table-III).

Table-III: Association between hand washing practice before taking food and type of residence

\begin{tabular}{|l|c|c|c|c|}
\hline \multirow{2}{*}{$\begin{array}{l}\text { Type of } \\
\text { Residence }\end{array}$} & \multicolumn{3}{|c|}{$\begin{array}{l}\text { Hand Washing Practice } \\
\text { before Food }\end{array}$} & \multirow{2}{*}{ Statistics } \\
\cline { 2 - 4 } & Yes & No & Total & \\
\hline Pucca & 31 & 2 & 33 & \multirow{2}{*}{$\mathrm{X} 2=9.64$} \\
\hline Semi Pucca & 26 & 4 & 30 & $\mathrm{df}=2$ \\
\hline Kacha & 31 & 25 & 46 & $\mathrm{p}<0.01$ \\
\hline Total & 88 & 31 & 109 & \\
\hline
\end{tabular}


Students having less monthly family income had significantly $(p<0.001)$ low habit of taking daily bath (Table-IV).

Table-IV: Association between habit of daily bath and monthly family income

\begin{tabular}{|c|c|c|c|c|}
\hline \multirow{2}{*}{$\begin{array}{c}\text { Monthly Income } \\
\text { (Taka) }\end{array}$} & \multicolumn{3}{|c|}{ Habit of Daily Bath } & \multirow[b]{2}{*}{ Statistics } \\
\hline & Yes & No & Total & \\
\hline$<5000$ & 31 & 32 & 63 & \multirow{4}{*}{$\begin{array}{c}\mathrm{X}^{2}=14.95 \\
\mathrm{df}=2 \\
\mathrm{p}<0.001\end{array}$} \\
\hline $5000-10000$ & 22 & 5 & 27 & \\
\hline$>10000$ & 17 & 2 & 19 & \\
\hline Total & 70 & 39 & 109 & \\
\hline
\end{tabular}

Students' parents having secondary or higher education had significantly $(p<0.001)$ high habit of taking daily bath $($ Table-V).

Table-V: Association between habit of daily bath and parent's education

\begin{tabular}{|c|c|c|c|c|}
\hline \multirow{2}{*}{ Parents Education } & \multicolumn{3}{|c|}{ Habit of Daily Bath } & \multirow[b]{2}{*}{ Statistics } \\
\hline & Yes & No & Total & \\
\hline Up to Primary & 28 & 33 & 61 & \multirow{4}{*}{$\begin{array}{c}\mathrm{X}^{2}=20.24 \\
\mathrm{df}=2 \\
\mathrm{p}<0.001\end{array}$} \\
\hline Secondary & 34 & 5 & 39 & \\
\hline HSC \& above & 8 & 1 & 9 & \\
\hline Total & 70 & 39 & 109 & \\
\hline
\end{tabular}

Students having Pucca and semi pucca type of residence had significantly $(p<0.05)$ high habit of wearing shoes in toilet (Table-VI).

Table-VI: Association between habit of wearing shoes in toilet and type of residence

\begin{tabular}{|c|c|c|c|c|}
\hline \multirow[t]{2}{*}{ Type of Residence } & \multicolumn{3}{|c|}{$\begin{array}{l}\text { Habit of Wearing Shoes } \\
\text { in Toilet }\end{array}$} & \multirow[t]{2}{*}{ Statistics } \\
\hline & Yes & No & Total & \\
\hline Pucca & 28 & 5 & 33 & \multirow{4}{*}{$\begin{array}{c}\mathrm{X}^{2}=6.35 \\
\mathrm{df}=2 \\
\mathrm{p}<0.05\end{array}$} \\
\hline Semi Pucca & 26 & 4 & 30 & \\
\hline Kacha & 30 & 16 & 46 & \\
\hline Total & 84 & 25 & 109 & \\
\hline
\end{tabular}

\section{Discussion}

In this study mean age of the students was $14.65 \pm 1.93$ years. Majority of the respondents were male $(53.21 \%)$ which is disimilar with the findings of the study conducted by Rahman $A^{10}$ where $63.33 \%$ were female this might be due to less number of rural girls studying higher class of school. Most of the respondents $(68.8 \%)$ family size was $5-8$ persons which is similar to the study by Rahman $A^{10}$. It was evident from the study that $42.2 \%$ respondents were living in kacha house. The finding is dissimilar to the study findings conducted by Chowdhury $F A^{11}$ where found $24.2 \%$ respondents were living in kacha house. This is because of the rural people are still living in kacha houses. Almost all the respondents had the habit of washing hand before meals and after defecation and daily teeth brushing which is similar with study findings conducted by Chowdhury $\mathrm{FA}^{11}$ among the food handlers of Dhaka University hostel messes. This result is also similar to the result found by Vivas AP et $a^{4}$.
Most the respondents $(77.1 \%)$ had habit of wearing shoes during use of toilet which was similar to the findings of the study conducted by Chowdhury FA ${ }^{11}$ but dissimilar to the finding of the study conducted by Nahar A and Alam ATM ${ }^{12}$ in 1999 among the children attending an urban clinic of Dhaka City where they found $15.9 \%$ children had habit of wearing shoes during use of toilet respectively. This may be due to increased awareness of the children about personal hygiene as they come to know about it through various sources in recent years. Almost all the respondents $(94.5 \%)$ had habit of washing hand after defecation which does not coincide with the study findings conducted by Nahar A and Alam ATM ${ }^{12}$ in 1999 who found only $11.1 \%$ children had habit of washing their hands after defecation. This may be due to increase awareness among the students as well as their parents regarding food borne diseases. This study reveals that $92.7 \%$ students had nail cutting habit weekly, 38.5\% had hair cleaning habit twice weekly and $43.1 \%$ had cloth cleaning habit twice weekly. These findings were more or less similar to the findings of the studies conducted by Dhar $S^{13}$ in Bangladesh where they found that clean nails and clean clothes among the respondents were $93.2 \%$ and $42.14 \%$ respectively but clean hair is dissimilar $(73.74 \%)$.

Only $4.6 \%$ had the habit of brushing teeth twice a day which is dissimilar with the study conducted by Rahman $A^{10}$ and Harikiran AG et al ${ }^{7}$ where the findings were $38.5 \%$ and $42 \%$ respectively. Poor hygiene practice was more among the respondents living in kacha house in case of hand washing before meal $(30.43 \%)$, taking daily bath $(52.17 \%)$ and wearing shoe during use of toilet (32.61\%) whereas $96.97 \%, 87.88 \%$ and $90.90 \%$ respondents living in pucca house were maintaining good personal hygiene respectively. The association between personal hygiene practice and accommodation status was found statistically significant. The study conducted by Chowdhury $\mathrm{FA}^{11}$ where he found that most $(52.8 \%)$ of the respondents living in semi pucca house were maintaining good hygiene practice whereas most of the respondents living in kacha house were maintaining poor hygiene practice $(78.9 \%)$. This is probably due to good housing and accommodation is important aid in maintaining good personal hygiene.

\section{Conclusion}

Awareness on personal hygiene is required for living a healthy life. Students' parents' educational qualification, monthly family income and accommodation status had significant impact on personal hygiene practice. Almost all the students had agreed that washing hand before meal and after defaecation prevents the spread of diseases. Proper knowledge on personal hygiene and regular practice keep them away from many diseases. So, effort should be made to aware every school going children about the benefits of regular practice of personal hygiene for a bright and healthy life. 


\section{References}

1. Park K. Textbook of Preventive and Social Medicine, 20th ed. M/s Banarsidas Bhanot, Jabalpur, India, 2009. Page-43, 451.

2. Pal BY. A handbook of Hygiene and Public Health, 13th ed, Page-563.

3. Oyibo PG. An article on basic personal hygiene: Knowledge and practices among school children aged 6-14 years in Abraka, Delta State, Nigeria, Wilolud Journals. Continental J Tropical Medicine 2012; 6(1):5-11.

4. Aboset $\mathrm{N}$ et al. Knowledge, attitudes and practices (KAP) of hygiene among school children in Angolela, Ethiopia. J Prev Med Hyg 2010; 51(2):73-9.

5. Rashid KM, Rahman M, Hyder S. Text book of Community Medicine and Public Health, 4th ed. RHM Publishers, Dhaka 2004:14-16,166.

6. UNICEF/IRC. A manual on school sanitation and hygiene, 2007. https://www.unicef.org/wash/files/Sch_e.pdf

7. Rashid KM, Rahman M, Hyder S. Text book of Community Medicine and Public Health, 4th ed. RHM Publishers, Dhaka 2004; 14-16,166.
8. Rashid KM, Rahman M, Hyder S. Text book of Community Medicine and Public Health, 4th ed. RHM Publishers, Dhaka 2004:14-16,166.

9. UNICEF. Study findings on hand washing with soap behaviour in Kenya under water and sanitation program. 2008. https://www.unicef.org/ wash/files/UNICEF_WASH_2008_Annual_Report_Final_27_05_2009.pdf

10. Rahman A. A study on practice regarding personal hygiene among school going and non school going children in a selected rural area. NIPSOM: Dissertation, June, 2002.

11. Chowdhury FA. Study on personal hygiene practice among the food handlers of Dhaka University Hostels, NIPSOM: Dissertation, June, 2008.

12. Nahar A and Alam ATM. Distribution of intestinal parasite infestation in children under 10 years in an urban clinic of Dhaka city and its impact on nutritional status of children, Mymensingh Med J 1999; 8(2):83-7.

13. Dhar S. Personal hygiene practice and distribution of intestinal parasite among the restaurant workers of Mohakhali area, Dhaka, NIPSOM: Dissertation, June, 2000. 